\title{
Wpływ poziomu wiedzy pielęgniarek opieki długoterminowej na właściwe prowadzoną profilaktykę i pielęgnację odleżyn
}

\author{
The influence of nurses knowledge about prevention and \\ treatment of pressure sores in long-term care
}

\author{
KATARZYNA ROGOWSKA ${ }^{1}$,TERESA SIEMIANOWSKA ${ }^{2}$ \\ ${ }^{1}$ Centrum Medyczne Grupa Zdrowie, Kraszewo-Czubaki 23a \\ 2Instytut Nauk o Zdrowiu, Państwowa Uczelnia Zawodowa we Włocławku Wojewódzki \\ Szpital Specjalistyczny we Włocławku, Oddział Chirurgii Ogólnej
}

DOI: https://dx.doi.org/10.21784/lwP.2019.022

ISSN: 2451-1846

\section{Streszczenie:}

Wstęp. Odleżyny to jeden z problemów długoterminowej opieki pielęgniarskiej nad pacjentami. Przysparzają one wiele cierpienia chorym i opóźniają ich powrót do zdrowia. W niektórych przypadkach mogą być nawet przyczyną śmierci. Pomimo rozwoju medycyny i coraz większych możliwości, skala tego zjawiska wciąż jest bardzo duża. Konieczne jest więc niezmiennie zgłębianie tematu odleżyn i rozwijanie świadomości społeczeństwa.

Cel. Celem niniejszej pracy jest ocena wiedzy pielęgniarek opieki długoterminowej w zakresie profilaktyki i pielęgnowania odleżyn.

Materiał i metody badawcze. W pracy posłużono się metodą sondażu diagnostycznego. Narzędzie badawcze stanowił autorski kwestionariusz ankiety, który zawierał dwadzieścia pytań zamkniętych. Badania przeprowadzono w Zakładzie Opiekuńczo-Leczniczym w Kraszewo-Czubaki w okresie od 01.01.2018 r. do 28.02.2018 roku. Została nimi objęta grupa pięćdziesięciu pracujących tam pielęgniarek. 
Wyniki. Na podstawie zgromadzonych danych wywnioskowano, że pielęgniarki opieki długoterminowej mają zróżnicowany poziom wiedzy na temat profilaktyki i pielęgnacji odleżyn.

Wnioski. 1. Pielęgniarki opieki długoterminowej mają zróżnicowany poziom wiedzy na temat zagadnień związanych $\mathrm{z}$ profilaktyką p/odleżynową. 2 Pielęgniarki opieki długoterminowej mają średni poziom wiedzy na temat infekcji w ranie. 3. Pielęgniarki opieki długoterminowej mają wysoki poziom wiedzy na temat opatrunków nowej generacji. 4. Uczestnictwo w kursach dotyczących profilaktyki i pielęgnacji odleżyn ma wpływ na to, jakie metody profilaktyki p/odleżynowej stosuje pielęgniarka w codziennej pracy zawodowej. 5. Stopień wykształcenia i staż pracy nie mają wpływu na poziom wiedzy pielęgniarek w zakresie profilaktyki i pielęgnacji odleżyn.

Słowa kluczowe: odleżyny, profilaktyka, wiedza, pielęgniarka

\section{Abstract:}

Intoduction. Pressure sores are one of the problems of long-term care. They cause a lot of suffering and delay patients' recovery. In many cases they can pose a life-threatening danger. Despite the huge development and improvements in the areas of medicine, the scale of this phenomenon is on the rise. That is why it is necessary to improve knowledge about pressure sores and increasing public awareness of pressure sores.

Aim. The aim of this study is to asses nurses' knowledge about prevention and treatment of pressure sores in long-term care.

Material and methods. A diagnostic survey was used together with the authors' self-designed questionnaire. The questionnaire included 20 closed questions. The study was carried out in Nursing Home facility in Krzeszewo Czubaki during the period from 01.01 .2018 to 28.02.2018. The study covered 50 nurses working in that facility.

Results. Based on the data gathered, it was concluded that in case of longterm nursing the personnel have diverse knowledge about prevention of pressure sores.

Conclusions. 1. Long-term care nurses have diverse knowledge level about prevention of pressure sores. 2. Long-term care nurses have average 
knowledge level about wound infection. 3. Long -term care nurses have high knowledge level about new generation dressing. 4. Participation in training devoted to pressure sores prevention has a significant influence on the use of methods for pressure sore prevention used in every day work. 5. Level of education and professional experience have no influence on nurses' knowledge about pressure sores prevention.

Key words: pressure sores, prevention, knowledge, nurse

\section{Wstęp}

Występowanie odleżyn jest częstym zjawiskiem w hospicjach i domach opieki. Dotyczy 14-34\% pensjonariuszy [1]. Odleżyny należą do ran przewlekłych. Ta ograniczona martwica obejmuje skórę, tkankę podskórną a także często mięśnie pokrywające wyniosłości kostne czy w ciężkich przypadkach nawet same kości [2]. Powstają w wyniku zaburzeń ukrwienia z powodu długotrwałego lub powtarzającego się ucisku na ciało chorego [3]. Wynikające $\mathrm{z}$ niego pogorszenie mikrokrążenia powoduje zamknięcie światła naczyń krwionośnych. Konsekwencją jest zwolnienie a następnie całkowite załamanie miejscowej przemiany komórkowej, które prowadzi do ich śmierci i powstania odleżyny $[4,5]$.

Odleżyny nie występują samoistnie jako jednostka chorobowa. Czas ich powstania zależy od ogólnego stanu pacjenta oraz stopnia czynników ryzyka. Miejscem szczególnie narażonym na ich powstanie jest dolna połowa ciała - aż 70\% ran tworzy się w jej obrębie (najwięcej w okolicy kości krzyżowej - 40\%) [6].

Przyczyny powstawania odleżyn. Do czynników wewnętrznych wpływających na powstawanie odleżyn należą: wiek, płeć, masa ciała, temperatura ciała, kondycja skóry, aktywność/unieruchomienie, czynność zwieraczy odbytu i cewki moczowej, odżywianie, gospodarka wodno-elektrolitowa, stan psychiczny, niewydolność układu neurologicznego i zaburzenia świadomości, niewydolność 
układu krążenia, niewydolność układu oddechowego, zabiegi usprawniające pracę układu kostno-mięśniowego, choroby współistniejące. Do czynników zewnętrznych zalicza się m.in.: długotrwały ucisk, tarcie, temperatura otoczenia, poziom opieki, bielizna pościelowa, złe warunki ekonomiczne, leki [7].

Profilaktyka przeciwodleżynowa polega na działach prowadzących do zmniejszenia ryzyka powstawania odleżyn - a gdy już wystąpią rany - do poprawy warunków ich gojenia. Zalicza się do nich m.in.: identyfikację chorych $\mathrm{z}$ grup ryzyka, rozpoznanie i eliminację czynników ryzyka, ochronę przed skutkami sił zewnętrznych ucisku i tarcia, zachęcanie chorego do ruchu, systematyczną kontrolę objawów (ból, duszność, przykurcze), codzienną dbałość o higienę i nawilżenie całego ciała oraz kontrolę stanu skóry, regularną i indywidualnie dostosowaną zmianę pozycji, stosowanie odpowiedniej bielizny i sprzętu pomocniczego, utrzymywanie ciepłego i odpowiednio nawilżonego powietrza w pomieszczeniu oraz prawidłowego natlenowania, dbałość o właściwe odżywienie oraz nawodnienie pacjenta, a także obserwację stanu psychospołecznego, edukację chorego i jego rodziny. Ważne jest by profilaktyka opierała się na indywidualnym podejściu do każdego pacjenta [8].

Ocena ryzyka i rozpoznanie pacjenta zagrożonego wystąpieniem jest możliwe dzięki starannemu prowadzeniu dokumentacji pielęgniarskiej z wykorzystaniem dostępnych skali. Najpopularniejszą i pionierską w dziedzinie jest punktowa skala oceny ryzyka odleżyn wg Doreen Norton. Uwzględnia 5 elementów: stan fizykalny, stan świadomości, aktywność, samodzielność w czasie zmiany pozycji ciała oraz funkcje zwieraczy odbytu i cewki moczowej. Każdy z czynników analizowany jest osobno - służy do tego czterostopniowa skala. Maksymalnie chory może otrzymać 20 punktów, a już od 14 zachodzi duże ryzyko postania odleżyn [9]. 
Priorytetem w zakresie profilaktyki jest redukcja nacisku na tkanki miękkie. Osiąga się to przede wszystkim przez zmianę pozycji podopiecznego. U chorych leżących, powinna być to pozycja ukośna (zakres $30^{\circ}$ ). By ułatwić proces i zadbać o bezpieczeństw i komfort chorego niezbędne jest stosownie sprzętu pomocniczego: łatwoślizgów, podnośników, pasów stabilizujących i transmisyjnych.

$\mathrm{W}$ profilaktyce p/odleżynowej bardzo istotne są codzienne czynności higieniczne. Skóra powinna być myta ciepłą wodą $\mathrm{z}$ dodatkiem delikatnych czyszczących. Najlepsze są w tym wypadku nieperfumowane mydła o pH 5,5. Skóra powinna być osuszana ze szczególnym uwzględnieniem fałd. Następnie zaleca się użycie środków zwiększających jej elastyczność i chroniących przed przesuszeniem, np. oliwki kosmetycznej czy oleju parafinowego. Profilaktycznie można zastosować opatrunki hydrokolidowe. Nie zaleca się stosowania pudrów i talków [10].

W przypadku upośledzenia funkcji zwieraczy ważne jest rozpoznanie przyczyny powstania dysfunkcji, np. zakażenia układu moczowego czy objawów ubocznych stosowania leków. W przypadku chorych z tymi dolegliwościami niezbędne jest stosowanie pampersów czy cewników (pęcherzowych lub zewnętrznych). Po każdorazowym wypróżnieniu istotna jest toaleta okolic intymnych oraz wysuszenie i natłuszczenie tych okolic [11].

Czynnikiem zapobiegania jest również odpowiednia dieta i uzupełnienie niedoborów pokarmowych - białka, mikroelementów, witamin i wody.

Do działań profilaktycznych można i warto włączyć rodzinę. Ważne jest zapoznanie jej z zasadami profilaktyki, przeprowadzenie instruktaży zmiany pozycji ułożeniowej i zasadami stosowania udogodnień. Przekazywanie wiedzy można wspomóc broszurami informacyjnymi, ulotkami czy plakatami. Życzliwe przejawy 
zainteresowania pacjentem zachęcają rodzinę do pomocy w opiece nad chorym [11].

\section{Cel}

Celem niniejszej pracy jest ocena wiedzy pielęgniarek opieki długoterminowej w zakresie profilaktyki i pielęgnowania odleżyn.

\section{Materiał i metody badawcze}

Badania przeprowadzono w Zakładzie Opiekuńczo-Leczniczym w Kraszewo-Czubaki w okresie od stycznia do lutego 2018 roku. Została nimi objęta grupa pięćdziesięciu pracujących tam pielęgniarek. Udział w badaniu był dobrowolny, ankieta została przeprowadzona anonimowo.

W pracy posłużono się metodą sondażu diagnostycznego, techniką ankietowania, autorskim kwestionariuszem ankiety oraz arkuszem kalkulacyjny Microsoft Excel. Kwestionariusz składał się z metryczki oraz głównej części - 20 pytań zamkniętych, które badały poziom wiedzy pielęgniarek opieki długoterminowej $\mathrm{w}$ zakresie profilaktyki i pielęgnowania odleżyn.

Tabela 1. Grupy wiekowe badanych.

\begin{tabular}{|l|l|l|}
\hline Przedział wiekowy & n- liczba pielęgniarek & $\%$ pielęgniarek \\
\hline $20-29$ lat & 10 & $20 \%$ \\
\hline 30-39 lat & 8 & $16 \%$ \\
\hline $40-49$ lat & 17 & $34 \%$ \\
\hline 50-59 lat & 15 & $30 \%$ \\
\hline
\end{tabular}

Źródło: wynik badań własnych.

W badaniach wyodrębniono cztery grupy wiekowe. W najliczniejszej grupie znalazły się pielęgniarki w wieku 40-49 lat - 
34\%. Pielęgniarki w przedziale wiekowym 50-59 lat stanowiły $20 \%$ respondentów. Najmniej liczną grupą okazały się pielęgniarki w wieku 30-39 lat - $16 \%$.

Tabela 2. Wykształcenie badanych.

\begin{tabular}{|l|l|l|}
\hline Wykształcenie & $\begin{array}{l}\mathrm{n} \text { - liczba } \\
\text { pielęgniarek }\end{array}$ & $\begin{array}{l}\% \\
\text { pielęgniarek }\end{array}$ \\
\hline $\begin{array}{l}\text { Liceum medyczne/studium } \\
\text { medyczne }\end{array}$ & 22 & $44 \%$ \\
\hline Licencjat pielęgniarstwa & 16 & $32 \%$ \\
\hline Magister pielęgniarstwa & 12 & $24 \%$ \\
\hline Inne & 0 & $0 \%$ \\
\hline
\end{tabular}

Źródło: wynik badań własnych

Absolwenci liceum lub studium medycznego stanowiły najliczniejszą grupę respondentów - 44\%. Pielęgniarki ze stopniem licencjata i magistra to kolejno 32 i $24 \%$. Żadna z biorących w badaniu osób nie zadeklarowała innego wykształcenia.

Tabela 3. Staż pracy zawodowej.

\begin{tabular}{|l|l|l|}
\hline Staż pracy & n-liczba pielęgniarek & $\%$ pielęgniarek \\
\hline $1-10$ lat & 12 & $24 \%$ \\
\hline $11-20$ lat & 11 & $22 \%$ \\
\hline $21-30$ lat & 14 & $28 \%$ \\
\hline $31-40$ lat & 13 & $26 \%$ \\
\hline
\end{tabular}

Źródło: wynik badań własnych

Staż pracy zawodowej wśród badanych był dość zróżnicowany. Najliczniejszą grupę stanowiły jednak pielęgniarki, których staż pracy wynosił między 21 a 30 lat. 


\section{Wyniki}

Tabela 4. Profilaktyka p/odleżynowa - poziom wiedzy.

\begin{tabular}{|l|l|l|}
\hline profilaktyka p/odleżynowa & $\mathrm{n}$ & $\%$ \\
\hline niski poziom wiedzy & 9 & $18 \%$ \\
\hline średni poziom wiedzy & 23 & $46 \%$ \\
\hline wysoki poziom wiedzy & 18 & $36 \%$ \\
\hline
\end{tabular}

Źródło: wynik badań własnych

W grupie badawczej przeważał średni poziom wiedzy na temat profilaktyki p/odleżynowej.

Tabela 5. Poziom wiedzy pielęgniarek na temat infekcji w ranie

\begin{tabular}{|l|l|l|}
\hline Infekcja w ranie & $\mathrm{n}$ & $\%$ \\
\hline niski poziom wiedzy & 4 & $8 \%$ \\
\hline średni poziom wiedzy & 26 & $52 \%$ \\
\hline Wysoki poziom wiedzy & 20 & $40 \%$ \\
\hline
\end{tabular}

Źródło: wynik badań własnych

Średni poziom wiedzy na temat infekcji w ranie dotyczył 52\% badanych. $8 \%$ respondentów wykazywało niski poziom wiedzy w wyżej wymienionym temacie. 
Tabela 6. Opatrunki nowej generacji - poziom wiedzy.

\begin{tabular}{|l|l|l|}
\hline opatrunki nowej generacji & $\mathrm{n}$ & $\%$ \\
\hline niski poziom wiedzy & 9 & $18 \%$ \\
\hline średni poziom wiedzy & 11 & $22 \%$ \\
\hline wysoki poziom wiedzy & 30 & $60 \%$ \\
\hline
\end{tabular}

Źródło: wynik badań własnych

Ponad połowę badanych charakteryzował wysoki poziom wiedzy w zakresie opatrunków nowej generacji (60\%). Niski poziom wiedzy wykazało $18 \%$ ankietowanych.

Tabela 7. Uczestnictwo w kursach dotyczących profilaktyki p/odleżynowej a stosowane metody profilaktyki p/odleżynowej.

\begin{tabular}{|c|c|c|c|c|c|c|c|c|c|c|c|c|c|c|c|c|c|c|}
\hline 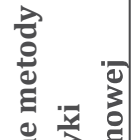 & 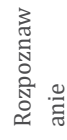 & & & & & 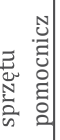 & & & & & & : & 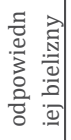 & & & & & \\
\hline $\begin{array}{ll} & \\
0 \\
0\end{array}$ & 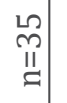 & $\delta^{\circ}$ & $\begin{array}{l}\underset{\sigma}{+1} \\
\stackrel{I}{=}\end{array}$ & ১o & 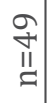 & $0^{\circ}$ & $\underset{=}{\stackrel{f}{I}}$ & $\partial^{\circ}$ & $\begin{array}{l}\stackrel{\infty}{+} \\
\stackrel{1}{I} \\
=\end{array}$ & $\partial^{\circ}$ & 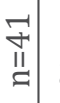 & ¿ & $\partial^{\circ}$ & $\underset{m}{m}$ & $a^{\circ}$ & $\underset{\underset{1}{\infty}}{\stackrel{\infty}{=}}$ & ○ & $\begin{array}{l}\ddot{\Xi} \\
\text { घू. } \\
\text { ฯ }\end{array}$ \\
\hline TAK & $\vec{N}$ & \begin{tabular}{l}
0 \\
\multirow{N}{0}{} \\
$\infty$ \\
$\infty$ \\
$\infty$
\end{tabular} & $\stackrel{\infty}{\sim}$ & 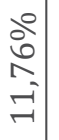 & $\widehat{N}$ & 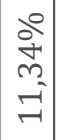 & $\hat{N}$ & 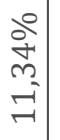 & $\stackrel{\infty}{\sim}$ & 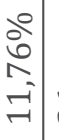 & & 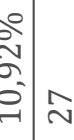 & 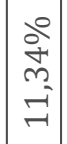 & & $\mid \begin{array}{c}8 \\
0 \\
-1 \\
-1 \\
-1\end{array}$ & $\stackrel{\bullet}{\sim}$ & 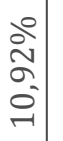 & $\stackrel{\infty}{\sim}$ \\
\hline NIE & $\Xi$ & 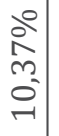 & $\vec{\sim}$ & $\begin{array}{l}80 \\
0 \\
0 \\
10 \\
10 \\
-1\end{array}$ & $\mathbb{N}$ & $\mid \begin{array}{c}0 \\
0 \\
0 \\
0 \\
-1 \\
-1\end{array}$ & $\stackrel{\sim}{\sim}$ & $\begin{array}{l}D^{0} \\
\vec{\infty} \\
+ \\
+\end{array}$ & $\stackrel{\curvearrowright}{\text { N }}$ & $\begin{array}{l}0 \\
\overrightarrow{0} \\
\infty \\
+ \\
+ \\
+\end{array}$ & $\stackrel{\sim}{\sim}$ & 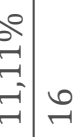 & $\mid \begin{array}{c}0 \\
10 \\
0 \\
0 \\
-1 \\
-1\end{array}$ & L & $\begin{array}{l}0^{0} \\
\stackrel{1}{1} \\
n^{-}\end{array}$ & & |c. & $\stackrel{\text { L }}{\rightarrow}$ \\
\hline $\begin{array}{l}\text { Istotno } \\
\text { ść X2 }\end{array}$ & 20,8 & & & & & & & & & & & & & & & & & \\
\hline $\mathrm{P}$ & 0,02 & & & & & & & & & & & & & & & & & \\
\hline
\end{tabular}

Źródło: wynik badań własnych 
Analiza wyników pokazuje zależność między uczestnictwem badanych $\mathrm{w}$ kursach dotyczących profilaktyki i pielęgnacji odleżyn a stosowanymi przez nich metodami profilaktyki. Ponad $11 \%$ ankietowanych, którzy przyznały, że edukowały pacjenta i jego rodzinę to osoby uczestniczące w kursach.

\section{Dyskusja}

Przeprowadzone badania pokazują, że pielęgniarki opieki długoterminowej mają różny poziom wiedzy na temat profilaktyki p/odleżynowej. Większość, bo $98 \%$, zna skalę Doreen Norton. 52\% ankietowanych zna skalę Douglas i Waterlow. Szczegółowej ocenie została poddana najpopularniejsza skala. $84 \%$ pielęgniarek potrafiło wskazać, że chory może w niej uzyskać 20 punktów. Zbadana została również znajomości czynników ocenianych według tej skali. Wyniki w kolejności rozpoznania przedstawiły się następująco: stan fizykalny - 94\%, funkcja zwieraczy odbytu i cewki moczowej - 76\%, aktywność - 72\%, stopień samodzielności przy zmianie pozycji ciała - 72\%, stan świadomości - $22 \%$.

Ostatnim zagadnieniem $\mathrm{z}$ tej kategorii była znajomość klasyfikacji wg Thorrance'a,. Należało podać ilość stopni odleżyn. 98\% ankietowanych odpowiedziało, że jest ich 5 .

$\mathrm{Na}$ przełomie 2015/2016 roku zostały przeprowadzone badania na grupie 400 aktywnych zawodowo pielęgniarek (388 kobiet i 12 mężczyzn). Wynik tych badań pokazał, że ogólny poziom wiedzy pielęgniarek na temat profilaktyki i leczenia odleżyn w odniesieniu do rekomendacji Polskiego Towarzystwa Leczenia Ran był na poziomie niezadowalającym. Średni wynik wynosił 5,85 w skali 0-10. Najtrudniejszymi zagadnieniami okazały się pytania dotyczące przeciwwskazań do stosowania materaca dynamicznego oraz rozpoznania odleżyny podskórnej [12]. 
Pielęgniarki długoterminowej opieki $\mathrm{w}$ badanej grupie charakteryzował również średni poziom wiedzy na temat infekcji $\mathrm{w}$ ranie. $74 \% \mathrm{z}$ nich odpowiedziało, że krwawienie nie świadczy o infekcji w ranie. $22 \%$ badanych odpowiedziało, że nie świadczy o niej ocieplenie okolic rany, a $4 \%$ - wzmożony wysięk. Jako pierwszy etap postępowania $\mathrm{w}$ przebiegu zakażenia rany $\mathrm{w}$ większości wskazano usunięcie tkanki martwiczej (48\%). 42\% ankietowanych wskazało włączenie antybiotykoterapii, a $10 \%$ w pierwszym kroku zastosowałoby opatrunek nowej generacji. W przypadku pytanie dotyczącego rodzaju antyseptyku zalecanego do oczyszczania rany przewlekłej, większość udzieliła prawidłowej odpowiedzi (78\%).

Bazaliński (i in.) w publikacji naukowej „Profilaktyka i leczenie odleżyn w praktyce personelu pielęgniarskiego oddziałów neurologicznych w odniesieniu do wytycznych Polskiego Towarzystwa Leczenia Ran" opisał problem metod oczyszczania odleżyn. Najwięcej osób biorących udział w badaniu (64\%) stosowało mechaniczne oczyszczanie przy użyciu gazy opatrunkowej i antyseptyków. $60 \%$ badanych korzystało z opatrunków specjalistycznych, a z interwencji chirurgicznej-38\%[13].

Badanie własne pokazały, że pielęgniarki opieki długoterminowej charakteryzuje wysokim poziom wiedzy na temat opatrunków nowej generacji. W przypadku pytania dotyczącego rozpoznania rodzaju opatrunków o dużych właściwościach pochłaniających $70 \%$ respondentów udzieliło prawidłowej odpowiedzi (opatrunki algininowe). 0 przeciwbakteryjnym działaniu opatrunków z jonami srebra wiedziało $62 \%$ badanych. Pielęgniarki w większości znały również główne zastosowanie opatrunków hyrdrokoloidowych. $68 \%$ z nich odpowiedziało, że służą do leczenie odleżyn od II do IV stopnia. Najtrudniejsze okazało się pytanie o ilość dni w jakich może pozostać na odleżynie błona poliuretanowa w odpowiednich 
warunkach. Jedynie $22 \%$ wskazało, że jest to 14 dni. Najwięcej, bo 54\% odpowiedziało, że 7 dni.

Badania zależność między uczestnictwem w kursach dotyczących profilaktyki i pielęgnacji odleżyn przez respondentów, a tym jakie metody profilaktyki przeciwodleżynowej stosują w swojej pracy. Ponad 11\% ankietowanych, którzy brali udział w takich kursach przyznało, iż edukuje pacjenta oraz jego rodzinę. 10\% pielęgniarek zadeklarowało również, iż wykonuje profilaktyczne opatrunki.

Ponad 16\% ankietowanych, które nie uczestniczyły w kursach przyznało, że stosuje w profilaktyce przeciwodleżynowej sprzęt pomocniczy i różnego rodzaju udogodnienia. Ponad 15\% tej grupy zmieniało pozycję złożeniową chorego. Tylko ok. 2\% badanych wykonywało profilaktyczne opatrunki i nieco ponad 3\% edukowało pacjenta oraz jego rodzinę.

W 2002 roku zostały przeprowadzone badania wśród pielęgniarek pracujących $w$ Klinice Neurologii. Miały one na celu określenie wiedzy pielęgniarek w zakresie profilaktyki i pielęgnowania odleżyn, a także wskazanie czynników utrudniających opiekę nad pacjentami z odleżynami oraz poznanie opinii pielęgniarek na temat przyjętego standardu postępowania. Badaniami objęto grupę 19 pielęgniarek w wieku 21 - 45 lat. Większość respondentów, bo aż $79 \%$, stanowili absolwenci liceum medycznego. Jak się okazało $95 \%$ badanej grupy deklarowało udział w szkoleniach wewnątrzoddziałowych dotyczących odleżyn. Wszystkie pielęgniarki uważały natomiast, że wiedza na temat odleżyn powinna być systematycznie uaktualniana $\mathrm{w}$ ramach szkoleń.

Przeprowadzone badania nie wykazały istotnej zależności pomiędzy stażem pracy badanych a ich poziomem wiedzy w zakresie profilaktyki i pielęgnacji odleżyn. Poziom wykształcenia również nie miał wpływu na wyniki. 
W badaniach przeprowadzonych w 2014 roku na grupie 100 pracowników personelu pielęgniarskiego uzyskano podobne wyniki. Średnia wieku ankietowanych wyniosła wówczas 37,9 roku $(S D=10,5)$ Kobiety stanowiły $95 \%$ badanych. Średni staż pracy zawodzie wyniósł 13,7 roku $(S D=10,6)$. W badaniu wzięło udział 33\% osób posiadających specjalistyczne kwalifikacje [14].

\section{Wnioski}

1. Pielęgniarki opieki długoterminowej mają zróżnicowany poziom wiedzy na temat zagadnień związanych $\mathrm{z}$ profilaktyką p/odleżynową.

2. Pielęgniarki opieki długoterminowej mają średni poziom wiedzy na temat infekcji w ranie.

3. Pielęgniarki opieki długoterminowej mają wysoki poziom wiedzy na temat opatrunków nowej generacji.

4. Uczestnictwo w kursach dotyczących profilaktyki i pielęgnacji odleżyn ma wpływ na to, jakie metody profilaktyki p/odleżynowej stosuje pielęgniarka w codziennej pracy zawodowej.

5. Stopień wykształcenia i staż pracy nie mają wpływu na poziom wiedzy pielęgniarek w zakresie profilaktyki i pielęgnacji odleżyn.

\section{Zalecenia dla praktyki pielęgniarskiej}

Dla zapewnienia wysokiej jakości świadczeń pielęgniarskich w placówkach opieki długoterminowej niezbędne jest podnoszenie poziomu wiedzy na temat zagadnień związanych z profilaktyką p/ odleżynową i pielęgnacją odleżyn. Kompleksowa opieka świadczona wobec pacjentów ma znaczący wpływ na ich dalszą jakość życia. 


\section{Bibliography/Bibliografia:}

1. Krasowski G., Kruk M. Leczenie odleżyn i ran przewlekłych. Wydawnictwo Lekarskie PZWL. Warszawa 2008:25-26.

2. Rauer K., Rauer J. Etiologia, patogeneza i profilaktyka odleżyn. Pielęgniarstwo Polskie. 2007,1(23):41-47.

3. Bożęcka M. Gdy ryzyko odleżyn rośnie. Magazyn Pielęgniarki i Położnej. 2013(3):26-27

4. Rosińczuk J., Uchmanowicz I. Odleżyny - profilaktyka i leczenie. Wydawnictwo Continuo. Wrocław 2014;15.

5. Malinowska K., Mikołajewska E.: Odleżyny - wspólna płaszczyzna działań pielęgniarskich i rehabilitacyjnych u pacjenta leżącego. Pielęgniarstwo Chirurgiczne i Angiologiczne. 2009(2);60-63.

6. Dzikowska M., Merklinger-Soma M., Gajda K. Analiza występowania odleżyn u pacjentów przebywających $\mathrm{w}$ szpitalu specjalistycznym o profilu zachowawczym. Probl. Pielęg. 2011;19(2):162-170.

7. Jakieła K., Krzemińska S., Borodzicz-Cedro A., Arendarczyk M. Czynniki wewnętrzne i zewnętrzne wpływające na powstawanie odleżyn u pacjentów leczonych na oddziale anestezjologii i intensywnej terapii. Pielęgniarstwo i Zdrowie Publiczne. 2014;(2):135-142.

8. Sopata M., Tomaszewska E., Głowacka A. Odleżyny - ocena ryzyka zagrożenia i profilaktyka. Pielęgniarstwo chirurgiczne i Angiologiczne. 2007;(4):165-169.

9. Cierzniakowska K., Szewczyk M., Łabuńska A., Michalak S., Popow A., Jawień A. Ocena ryzyka rozwoju odleżyn na podstawie skali Doreen Norton. Leczenie Ran. 2011;8(1):7-13. 